\title{
Description of a new species of Bryconomericus (Teleostei, Characidae) from the basin of the Golfo de Paria, northeastern Venezuela
}

\author{
César ROMÁN-VALENCLA \\ Universidad del Quindio, Departamento de Biología, AA. 460, Armenia, Colombia. \\ E-mail: croman@cocora.uniquindio.edu
}

\begin{abstract}
The new fish species Bryconamericus lassorum is described from the basin of the Golfo de Paria, northeastern Venezuela. It can be distinguished from other species of Bryconamericus by the possession of a foramen on the maxilla, located adjacent to the anterior tooth-bearing bone, by the presence of a large, elongate apophysis on the orbitosphenoid, and by the insertion of the proximal and radial components of the dorsal fin pterygiophores between the neural spines of the $13-19$ th vertebrae.
\end{abstract}

Key words: Characiformes, tropical fish, Venezuela, Bryconamericus.

Bryconamericus is a speciose and complex genus of the family Characidae, widely distributed in Central and South America (Román-Valencia, 2000a). Species of the gents are abundant both in small brooks and on the banks of larger running waters, with high concentrations of dissolved oxygen (ca. $8 \mathrm{mg} / \mathrm{l}$ ) and almost neutral $\mathrm{pH}$ (Román-Valencia, 1998, 2000a, b, in press), Seven valid species are recognized for Venezuela $(B$. alpha, B. breviceps, B. cismontanus, $B$. heretesthes, B. loisae, B. motatanensis and B. meridae) being the genus distributed throughout all the areas of the country (Román-Valencia, 2000a). The purpose of this paper is to describe a new spcies of Bryconamericus from Venezuela.

\section{ME'THODS AND MATERIAL}

Measurements on 14 specimens were made with digital calipers to $0.01-\mathrm{mm}$ precision, and expressed as percentage of the standard (SL) and head lengths (HL) (Table 1). Fin-ray, scale and teeth counts were made with the aid of a stereomicroscope, a dissecting needle and, occasionally, methyl blue staining solution. Measurements and counts were taken on the left side, except when that side was too damaged. Counts and measurements were recorded following the methodology described in Vari \& Siebert (1990).

Observations of cartilage and bone were made on two cleared and stained specimens following the modifications by Song \& Parenti (1995) of the method outlined in Taylor \& Van Dyke (1985).
Bone nomenclature follows Weitzman (1962) and Vari (1995). Specimens were compared with type and non-type material deposited in the following institutions: Instituto de Ciencias Naturales, Universidad Nacional de Colombia, Bogotá (ICNMNH), Field Museum of Natural History, Chicago (FMNH), Laboratorio de Ictiología, Departamento de Biologia, Universidad del Quindio, Armenia, Colombia (IUQ), Museo de Biología, Ins" tituto de Zoología Tropical, Universidad Central de Venezuela, Caracas (MBUCV), Museo de Historia Natural La Salle, Caracas, Venezuela (MHNLS), and Division of Fishes, National Museum of Natural History, Smithsonian Institution, Washington, D.C. (USNM).

The 22 morphometric characters examined in this study (Table 1) were submitted to a principal component analysis (PCA), using the computer software SPAD-Windows version 3.21. An analysis of variance of some morphometric characters for the new species, $B$. ichoensis, and B. multiradiatus, was carried out using the computer software Statgraphics version 2.6-DOS.

Comparative material. Bryconamericus alpha: FMNH 56647, one paratype; Colombia, Villavicencio, 1913; González. - Bryconamericus beta: FMNH 56649 , one paratype; Colombia, Villavicencio, 1913; González. - Bryconamericus breviceps: USNM 120274 syntypes, two specimens; Brazil, Rio Gotaz, senhor Honorio, 1865.Bryconamericus motatanensis: USNM 121479 paratype, ten specimens; Venezuela, lago de Maracaibo basin, Rio Motatan $4 \mathrm{Km}$ arriba de Motatan; 25 March 1942; L.P. Schultz. USNM 
Table 1. Morphometric and meristic data of B. lassorum n. sp. Standard and total lengths in mm. Mean values within parentheses.

\begin{tabular}{|c|c|c|}
\hline Morphometric: & $\begin{array}{c}\text { Paratype } \\
n=13\end{array}$ & Holotype \\
\hline Standard length (mm) & $24.94-35.56(31.06)$ & 33.01 \\
\hline Total length & $32.23-44.17(40.47)$ & 41.00 \\
\hline \multicolumn{3}{|l|}{ Percentages of SL: } \\
\hline 1. Body depth & $28.10-33.41(29.89)$ & 29.81 \\
\hline 2. Snout-dorsal fin distance & $52.27-55.74(53.78)$ & 54.56 \\
\hline 3. Snout-pectoral fin distance & $22.45-28.73(26.46)$ & 27.29 \\
\hline 4. Snout-pelvic fin distance & $44.83-48.61(46.25)$ & 46.23 \\
\hline 5. Snout-anal fin distance & $57.57-62.07(59.24)$ & 59.25 \\
\hline 6. Dorsal fin-hypurals length & $46.86-55.17(49.40)$ & 46.91 \\
\hline 7. Dorsal fin -pectoral fin length & $37.21-42.60(40.68)$ & 40.96 \\
\hline 8. Dorsal fin-anal fin length & $28.61-33.44(31.28)$ & 31.02 \\
\hline 9. Dorsal fin length & $22.34-26.79(24.55)$ & 23.36 \\
\hline 10. Pectoral fin length & $21.28-26.91(24.05)$ & 24.05 \\
\hline 11. Pelvic fin length & $14.96-19.69(17.39)$ & 17.90 \\
\hline 12. Anal fin length & $17.08-20.92(19.63)$ & 18.42 \\
\hline 13. Caudal peduncle depth & $7.95-10.48(9.35)$ & 9,02 \\
\hline 14. Caudal peduncle length & $6.38-10.95(8.12)$ & 7.85 \\
\hline 15. Head length & $22.76-24.61(23.63)$ & 23.45 \\
\hline \multicolumn{3}{|l|}{ Percentages of HL: } \\
\hline 16. Snout length & $24.58-31.63(27.59)$ & 25.45 \\
\hline 17. Postorbital distance & $33.33-39.07(35.69)$ & 34.33 \\
\hline 18. Orbital diameter & $33.44-49.27(43.88)$ & 40.05 \\
\hline 19. Maxilla length & $16.34-25.32(22.63)$ & 24.32 \\
\hline 20. Upper jaws length & $26.52-36.47(30.69)$ & 28.04 \\
\hline 21. Interorbital distance & $32.17-37.12(34.92)$ & 33.17 \\
\hline \multicolumn{3}{|l|}{ Meristic: } \\
\hline Lateral-line scales & $35-36$ & 36 \\
\hline Scale rows between dorsal-fin origin and lateral line & $5-6$ & 5 \\
\hline Scale rows between anal-fin origin and lateral line & $5-6$ & 5 \\
\hline Scale rows between pelvic-fin origin and lateral line & $4-5$ & 4 \\
\hline Predorsal median scales & - & - \\
\hline Dorsal-fin rays & iii, 7 & iii, 7 \\
\hline Anal-fin rays & ч,25-26 & $v, 26$ \\
\hline Pelvic-fin rays & $\mathrm{ii}, 6$ & $\mathrm{ii}, 6$ \\
\hline Pectoral-fin rays & ii, $9-10$ & ii, 9 \\
\hline
\end{tabular}

121.478, paratype, 74 specimens; Venezuela, Rio Motatan system, Río San Juan at bridge south of Mene Grande; 20 March 1942; L.P. Schultz. - IUQ 394 (before MBUCV 7416), 30 specimens; Venezuela, estado Portuguesa, Río Portuguesa system, Rio Las Marias in Guanare; 26 September 1973; Mago F, O. Silva, H. López, A. Machado, L. Aguara. - B. multiradiatus: ICNMNH 82, Holotype; Colombia, Departamento del Chocó, municipio de río Sucio, cuenca río Atrato, Río Sucio; 8 September 1959; G. Dahl. ICNMNH 4911, four specimens; Colombia, Departamento del Chocó, municipio de Río Sucio, Río Atrato; 8 septiembre 1959; G. Dahl. ICNMNH 1.568, 15 specimens; Co- lombia, Departamento del Chocó, municipio de Quibdó, Río Atrato, caño ciénaga de Ipurrú en San Antonio de Padua; 24 September 1988; C. RománV. \& E. Puentes.

\section{RESULTS}

\section{Bryconamericus lassorum new species}

(Table 1; Figs. 1-5)

Holotype. MNHLS 9407, Collected by V. Ponce, C. Colonnella, and M. Curvelo; Venezuela, Monagas State, stream El Caño, $10 \mathrm{~km}$ from 


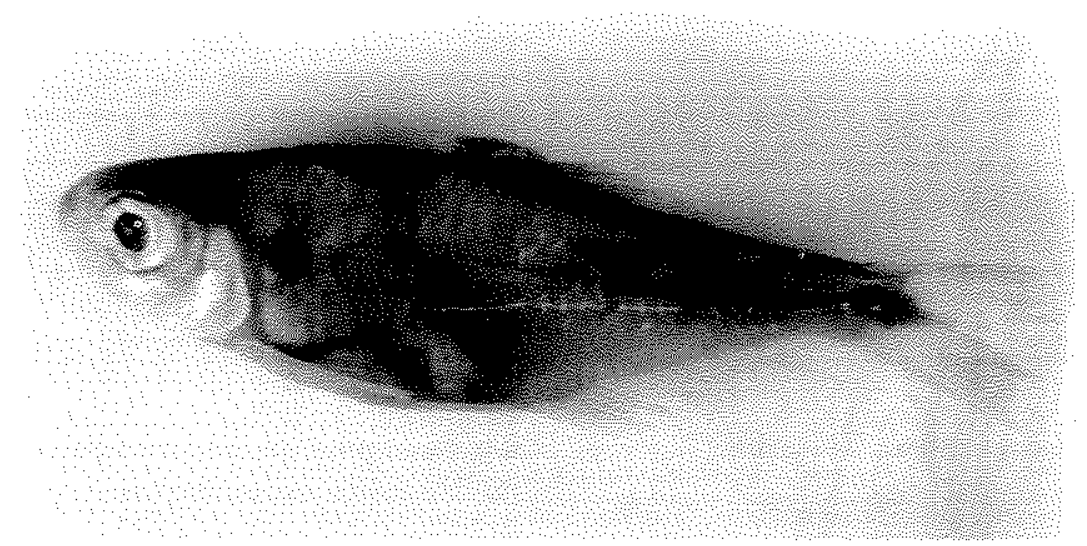

Fig. 1. Bryconamericus lassorum n. sp., holotype, $33.01 \mathrm{~mm} \mathrm{~S}$, female, MNHLS 9407, Venezuela, El Caño, $10 \mathrm{~km}$ from Aragua to Maturin, Golfo Paria basin, Rio Guarapiche system, San Juan.

Aragua to Maturin, Rio Guarapiche-San Juan system, Golfo de Paria basin $\left(9^{\circ} 55^{\prime} 10^{\prime \prime} \mathrm{N} \& 63^{\circ}\right.$ $24^{\prime} 53^{\prime \prime}$ W) 13 February 1991.

Paratypes. 11 specimens collected with the holotype: MHNLS 14424. - two specimens collected with holotype (C \& S): MHNLS 14424.

Diagnosis. Bryconamericus lassorum is readily distingtished from its congeners by the maxilla having a foramen located adjacent to the toothbearing anterior border of the bone (Fig. 2), by an undividied parasphenoid, by an orbitosphenoid with a large, elongate apophysis (Fig. 3), and by the proximal and radial components of the dorsal fin pterygiophores located between neural spines 13-19.

Description. Body short and robust. Dorsal profile of head oblique; area above orbits convex. Dorsal profile of body curved from supraoccipital to dorsal fin origin, slightly oblique from last dorsal fin ray to caudal fin base. Ventral profile of body convex from snout to anal fin base, convexity more pronounced beyond posterior part of pectoral fins. Greatest body depth anterior to dorsal fin origin. Caudal peduncle laterally compressed in all specimens. Head and snout short; jaws equal, mouth terminal; lips soft and flexible, not covering external tooth row of premaxilla; ventral border of upper jaw slightly concave; maxilla ending posteriorly at level of anterior border of orbit. Right and left nostrils proximate; opening of posterior nostrils vertically ovoid; opening of anterior nostrils with posterior membranous flap. Eyes without membranous covering.

Four infraorbital bones present, all with laterosensory canal; third infraorbital long, wide, with ventral and posterior borders in contact with preopercle. Supraorbital absent. Premaxilla with short lateral process and two rows of teeth; outer row with $4-5$ tricuspidate teeth arranged in straight line. Inner row with four teeth pentacuspid, with central cuspid slightly larger. Maxilla short with posterior tip not reaching anterior border of second infraorbital. Maxilla with 3-4 teeth, pentacuspidate, with central cusp slightly larger, teeth located on anterior and ventral margins of bone; maxilla with a foramen located adjacent to anterior border of tooth bearing bone. Dentary with four large teeth followed by four small teeth. All dentary teeth pentacuspidate, with central cusp slightly larger. Dentary joined to articular through three apophyses.

Rhinosphenoid separated posteriorly from orbitosphenoid by mesethmoid cartilage. Orbitosphenoid with short, wide apophysis present. Parasphenoid slender and undivided. Mesethmoid cartilage contacting dorsal and lateral margins of rhinosphenoid and extending to anterior extreme of parasphenoid. Anterior portion of parasphenoid covering posterodorsal surface of vomer; posterior portion of parasphenoid in contact with prootic and basioccipital. Nasal bones present. Dorsal fin margin rounded, second ray simple and first two branched rays longest. Radial and proximal components of all dorsal fin pterygiophores inserted between neural spines 13-19; proximal radials keeled. Five supraneurals between head and anterior dorsal fin. Lower extreme of bones projected between neural spines. Dorsal fin proximal radials wide, with keel present.

Pectoral girdle with a sharp dorsal process on cleithrum, reaching $2 / 3$ of supracleithrum. Cleithrum long, located at level of posterior middle 


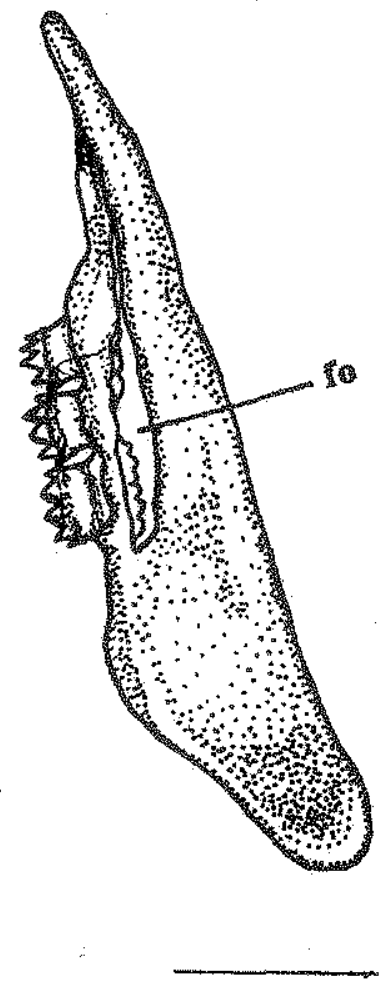

Fig. 2. Left maxilla of Bryconamericus lassorum $n$. $s p$. indicating the foramen (fo). Scale bar: $1 \mathrm{~mm}$.

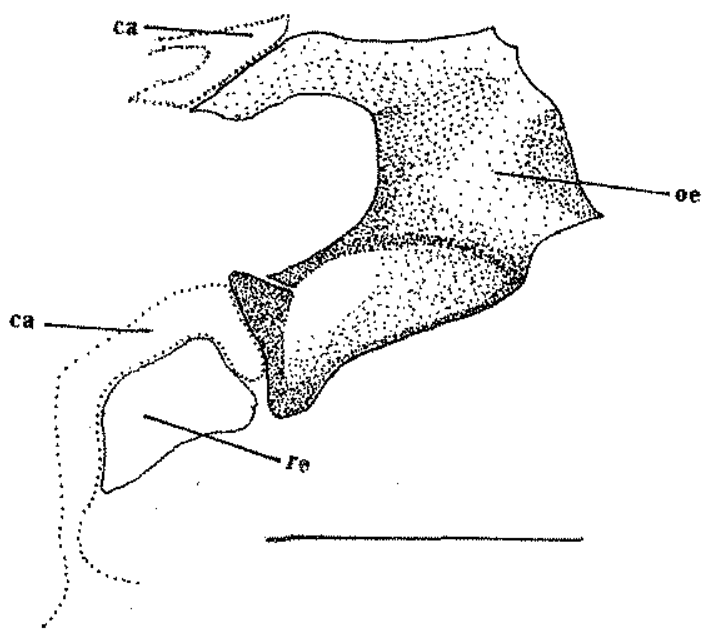

Fig. 3. Orbitosphenoid (oe), rhinosphenoid (re), and cartilage (ca) of Bryconamericus lassorum $n$. $s p$. Scale bar: $1 \mathrm{~mm}$. part of opercle. Ten proximal radials. Pelvic fin margin rounded, with top of fin reaching anal fin origin. Pelvic bone an elongated structure located parallel to belly; pelvic bone tip not straight; ischiac process a short structure, not straight, with two apophyses on posterior edge.

Anterior four anal fin pterygiophores inserted after third caudal vertebral spine. First pterygiophore associated with first four anal rays. Anal fin with 1-2 scale rows covering base of anal-fin rays. Caudal fin bifurcated with large lobus ending in filaments or pointed tips. Caudal-fin rays 5-7/ 8-9. Caudal fin unscaled. With 35-36 pored lateral line scales, extending from supracleithrum to hypural joint. Lateral line pores forming slight curve between first and fourth scale with rest in straight line. Total vertebrae 37 .

Secondary sexual dimorphism. Males with row of short bent hooks on each ray segment of pelvic and anal fins. Branched anal fin rays 1 to 8 with spines, spines on rays 3 to 8 placed on branched segment. All branched pelvic fin rays with 16-18 spines on basal two thirds.

Color in alcohol. Taken primarily from type material. Background body color brown to yellowbrown. Dark band visible on lateral surface of body from opercle to caudal peduncle. A dark vertically elongate humeral blotch present posteriorly to opercle at level of lateral line. Region dorsaly to lateral line more darkly pigmented than ventral region of body. Intense brown chromatophores on upper and lower jaws. Chromatophores on caudal fin more intense.

Comparisons. Bryconamericus lassorum is similar to $B$. ichoensis, but differs in the position of the insertion of the pectoral fin $(22.45-28.73 \%$ of $\mathrm{SL}, \mathrm{n}=14$ in $B$. lassorum; $27.39-32.39 \%$ of SL, $\mathrm{n}=11 \mathrm{in} B$. ichoensis; analysis of variance $\mathrm{F}=4.27$; $\mathrm{p}=0.05)$, in the head length $(22.76-24.61 \%$ of SL, $\mathrm{n}=14$ in B. lassorum; $25.86-29.76 \%$ of $\mathrm{SL}, \mathrm{n}=11$ in $B$. ichoensis; analysis of variance $F=6.65 ; \mathrm{p}=$ 0.05 ), in the length of the maxilla (24.56-34.79\% of HL, $\mathrm{n}=14$ in $B$. lassorum; $22.76-24.61 \%$ of HL, $\mathrm{n}=11$ in $B$. ichoensis; analysis of variance $\mathrm{F}=$ $31.27 ; p=0.05$ ) and in the number of branched anal fin rays (25-26 in $B$. lassorum; 27-30 in $B$. ichoensis) (Table 1, and Román-Valencia, 2000b). The Principal Component Analysis (Fig. 4) indicates that the two taxa differ on axis 1 by the anal and pectoral fin origin position. On axis 2 they differ by the maximum body depth, length of the maxilla, length of the caudal peduncle, and by the dorsal fin rays. The first component explains $75.15 \%$ of total variance, and the first 


\section{Component 2}

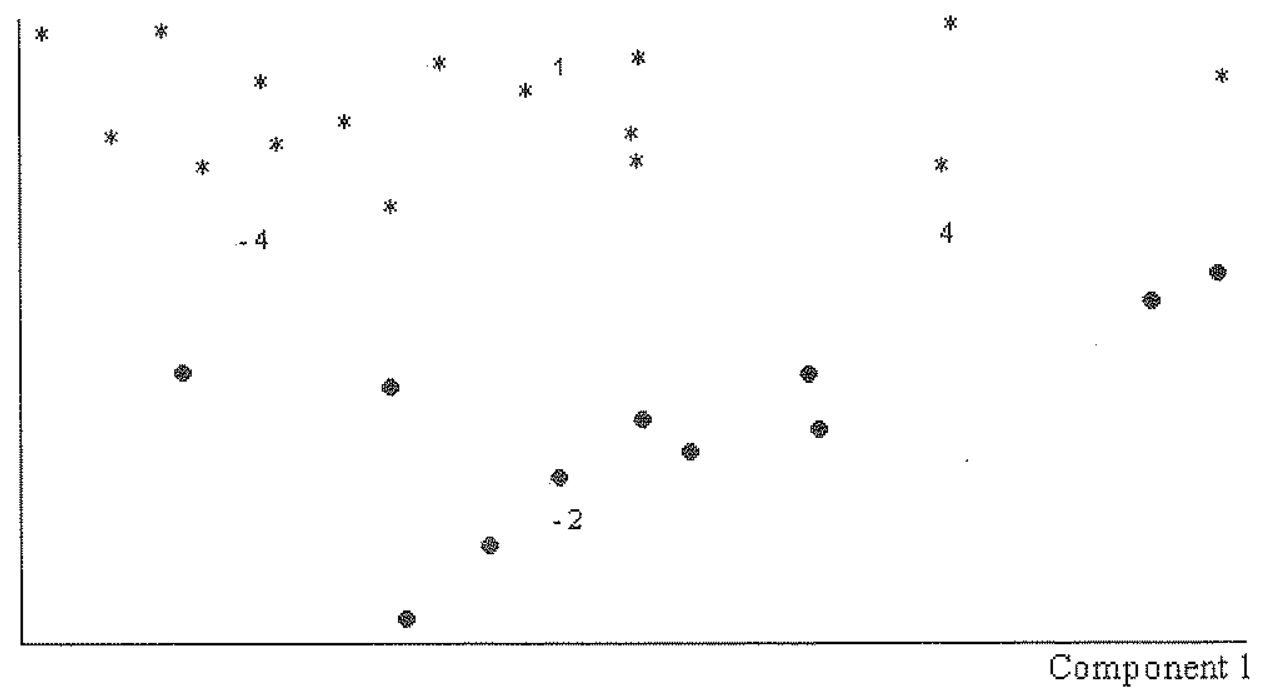

Fig. 4. Representation of the two principal components of the morphometric data (PC1 on axis X, PC2 on axis $\mathrm{Y}$ ) for B. lassorum n. $s p$. (dots) and B. ichoensis (asterisks).

\section{Component 2}

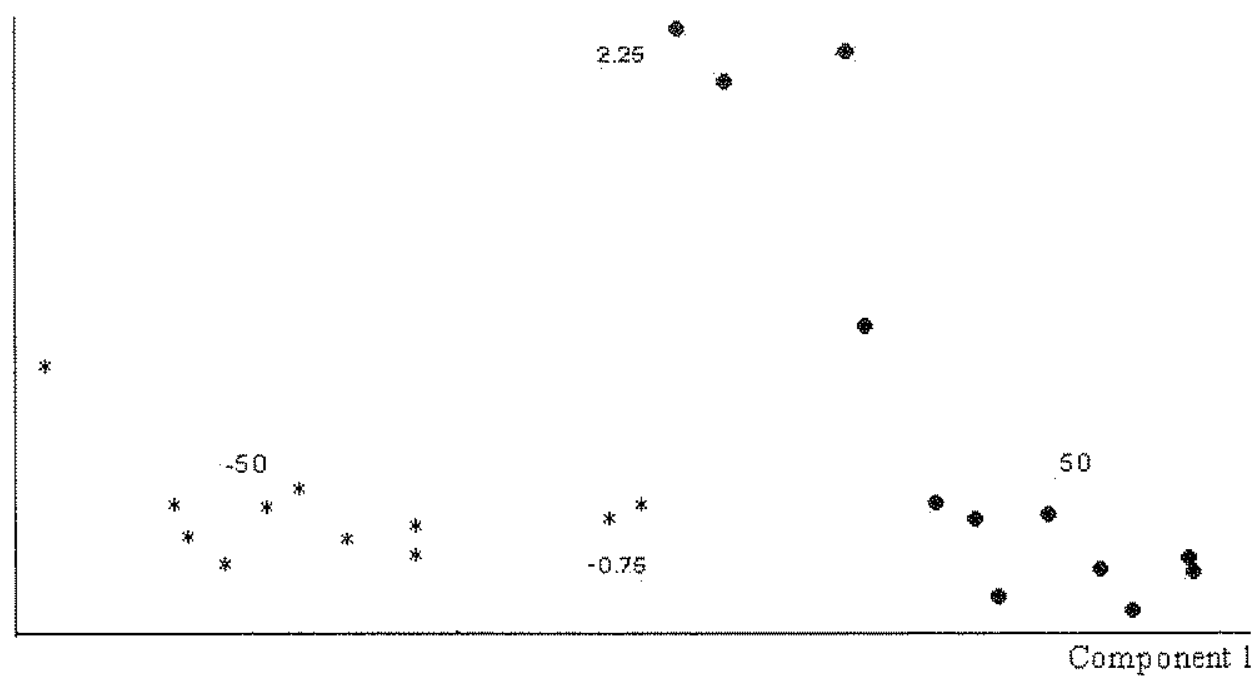

Fig. 5. Representation of the two principal components of the morphometric data ( $\mathrm{PC} 1$ on axis X, PC2 on axis Y) for B. lassorum n. sp. (asterisks) and B. multiradiatus (dots).

and second component jointly explain $82.43 \%$ of the total variance.

Bryconamericus lassorum is also similar to $B$. multiradiatus. It differs in body depth $(28,10-$ 33.42 , mean $29.89 \%$ of SL, $\mathrm{n}=14$ in $B$. lassorum; 20.93-27.58, mean $24.52 \%$ of SL, $\mathrm{n}=20$ in $B$. multiradiatus; analysis of variance $\mathrm{F}=70.06 ; \mathrm{p}=$ $0.05)$, and in dorsal to anal fin distance (28.6133.44 , mean $31.28 \%$ of SL, $\mathrm{n}=14$ in B. lassorum; 21.48-28.62, mean $25.44 \%, \mathrm{n}=20$ in $B$. multiradiatus; analysis of variance $\mathrm{F}=75.72 ; \mathrm{p}=$ 0.05). The Principal Component Analysis (Fig. 5) 
shows that these two taxa differ on axis 1 by the dorsal fin position in relation to the anal fin, and by the head length. On axis 2 they differ by the dorsal and pelvic fin lengths, by the caudal peduncle length, and by the distance between the snout and the pectoral fin origin. The first component explains $85.99 \%$ of total variance, and the first and second components jointy explain $91.79 \%$ of total variance.

Etymology. The species is named after the Spanish ichthyologists Carlos Lasso and Oscar Lasso-Alcalá (MHNLS), in recognition for their contributions to the study and preservation of Neotropical fish.

\section{ACKNOWLEDGEMENTS}

The following institutions financed the study: Departamento de Biología, Universidad del Quindio, Armenia, Colombia; Colciencias; Smithsonian Tropical Research Institute, Naos, Panamá (STRI) and La Fundación para la Investigación y la Tecnología del Banco de la República de Colombia. I am very grateful to the following persons and museums for loans of material under their care: Francisco Provenzano, Antonio Machado-Allison and Alberto Marcano (MBUCV); Carlos Lasso and Oscar Lasso-Alcalá (MHNLS); Barry Chernoff and Mary Anne Rogers (FMNH); Richard P. Vari and Susan L. Jewett (USNM); Germán Galvis and Iván Mojica (ICNMNH). Raquel Ruiz (IUQ) prepared figures 2 and 3 . This paper benefited from corrections and suggestions from Richard P. Vari (USNM) and two anonymous reviewers.

\section{BIBLIOGRAPHY}

Román-Valencia, C. 1998. Descripción de una nueva es" pecie de Bryconamericus (Characiformes, Characidae) para la cuenca alta de los ríos Ariari y Meta, Colombia. Actual. Biol. 20(69): 109-114.

- 2000a. Revisión sistemática de las especies del género Bryconamericus (Teleostei: Characidae) para Centroamérica y el Norte de Suramérica. Tesis Ph.D., Departamento de Biología, Facultad de Ciencias, Universidad del Valle, Cali, Colombia, $182 \mathrm{pp}$.

- 2000b. Tres nuevas especies de Bryconamericus (Ostariophysi: Characidae) de Colombia, y diagnós. tico del género, Rev. Biol. Trop. 48 (2/3): 449m464.

- In press. Descripción de una nueva especie de Bryconamericus (Ostariophysi, Characidae) del alto río Suárez, cuenca del Magdalena, Colombia. Boll. Mus. reg. Sci. nut. Torino 18 (2).

Song, J. \& L.R. Parenti. 1995. Clearing and staining whole fish specimens for simultaneous demonstration of bone, cartilage and nerves. Copeia (1): 114-118.

Taylor, W.R. \& G.C. Van Dyke. 1985. Revised procedures for staining and clearing small fishes and other vertebrates for bone and cartilage study. Cybium 9:107-119.

Vari, R.P. 1995. The Neotropical fish family Ctenoluciidae (Teleostei: Ostariophysi: Characiformes): Supra and intrafamilial phylogenetic relationships, with a revisionary study. Smithson. Contr. Zool. 564:1-97.

Vari, R.P.\& D.J. Siebert. 1990. A new, unusually sextally dimorphic species of Bryconamericus (Pisces: Ostariophysi: Characidae) from the Peruvian Amazon. Proc Biol Soc Wash. 103 (3): 516-524.

Weitzman, S.H. 1962. The osteology of Brycon meeki, a generalized characid fish, with an osteological definition of the family. Stanford Ichthy. Bull. 8 (1): 1-50.

Recibido: 26-XI-2001

Aceptado: 5-V-2002 